\title{
Correction to: Prospective observational study on Pazopanib in patients treated for advanced or metastatic renal cell carcinoma in countries in Asia Pacific, North Africa, and Middle East regions: PARACHUTE study
}

\author{
Mustafa Erman', Bivas Biswas², Pongwut Danchaivijitr ${ }^{3}$, Lingwu Chen ${ }^{4}$, Yoke Fui Wong ${ }^{5}$, Tarek Hashem ${ }^{6}$, \\ Chun Sen Lim7, Bulent Karabulut ${ }^{8}$, Hsiao-Jen Chung ${ }^{9}$, Chandrasekhar Chikatapu ${ }^{10}$, Sara Ingles ${ }^{11}$, \\ Khemaies Slimane ${ }^{12}$ and Ravindran Kanesvaran ${ }^{13^{*}}$ \\ Correction to: BMC Cancer 21, 1021 (2021) \\ https://doi.org/10.1186/s12885-021-08738-z
}

Following publication of the original article [1], the authors identified an error in the author names of Mustafa Erman, Bivas Biswas, Pongwut Danchaivijitr, Lingwu Chen and Chandrasekhar Chikatapu. The given names and family names were erroneously transposed.

Further to this, figure 1 has been updated. The line colors in "C" section for "Poor" and "Unknown" have been changed to align with Figure $\mathrm{B}$ and legend to match the line colors.

The author group has been updated above and the original article [1] has been corrected.

\section{Author details}

${ }^{1}$ Medical Oncology, Hacettepe University, Ankara, Turkey. ${ }^{2}$ Medical Oncology, Tata Medical Center, Kolkata, West Bengal, India. ${ }^{3}$ Medical Oncology, Siriraj Hospital, Mahidol University, Bangkok, Thailand. ${ }^{4}$ Medical Oncology, The First Affiliated Hospital of Sun Yat-sen, Guangzhou, Guangzhou, Guangdong Province, China. ${ }^{5}$ Radiotherapy and Oncology, National Cancer Institute, Putrajaya, Malaysia. ${ }^{6}$ Medical Oncology, Dr. Tarek Hashem's Clinic, Cairo,
Egypt. ${ }^{7}$ Clinical Oncology, Sultan Ismail Hospital, Johor Bahru, Malaysia. ${ }^{8}$ Medical Oncology, Ege University, Izmir, Turkey. ${ }^{9}$ Department of Urology, Taipei Veterans General Hospital and Department of Urology, College of Medicine and Shu-Tien Urological Research Center, National Yang Ming Chiao Tung University, Taipei, Taiwan. ${ }^{10}$ Oncology, Novartis Healthcare Pvt. Ltd., Hyderabad, Telangana, India. "'Oncology, Novartis Pharma AG, Basel, Switzerland. ${ }^{12}$ Oncology, Novartis Pharma SAS, Rueil-Malmaison, France.

${ }^{13}$ Division of Medical Oncology, National Cancer Centre Singapore, Singapore, Singapore.

Published online: 09 November 2021

\section{Reference}

1. Erman M, Biswas B, Danchaivijitr $P$, et al. Prospective observational study on Pazopanib in patients treated for advanced or metastatic renal cell carcinoma in countries in Asia Pacific, North Africa, and Middle East regions: PARACHUTE study. BMC Cancer. 2021;21(1):1021. https://doi.org/10.1186/s12 885-021-08738-z.

The original article can be found online at https://doi.org/10.1186/s12885021-08738-z

* Correspondence: ravindran.kanesvaran@singhealth.com.ss

${ }^{13}$ Division of Medical Oncology, National Cancer Centre Singapore, Singapore, Singapore

Full list of author information is available at the end of the article

C The Author(s). 2021 Open Access This article is licensed under a Creative Commons Attribution 4.0 International License, which permits use, sharing, adaptation, distribution and reproduction in any medium or format, as long as you give appropriate credit to the original author(s) and the source, provide a link to the Creative Commons licence, and indicate if changes were made. The images or other third party material in this article are included in the article's Creative Commons licence, unless indicated otherwise in a credit line to the material. If material is not included in the article's Creative Commons licence and your intended use is not permitted by statutory regulation or exceeds the permitted use, you will need to obtain permission directly from the copyright holder. To view a copy of this licence, visit http://creativecommons.org/licenses/by/4.0/. The Creative Commons Public Domain Dedication waiver (http://creativecommons.org/publicdomain/zero/1.0/) applies to the data made available in this article, unless otherwise stated in a credit line to the data. 


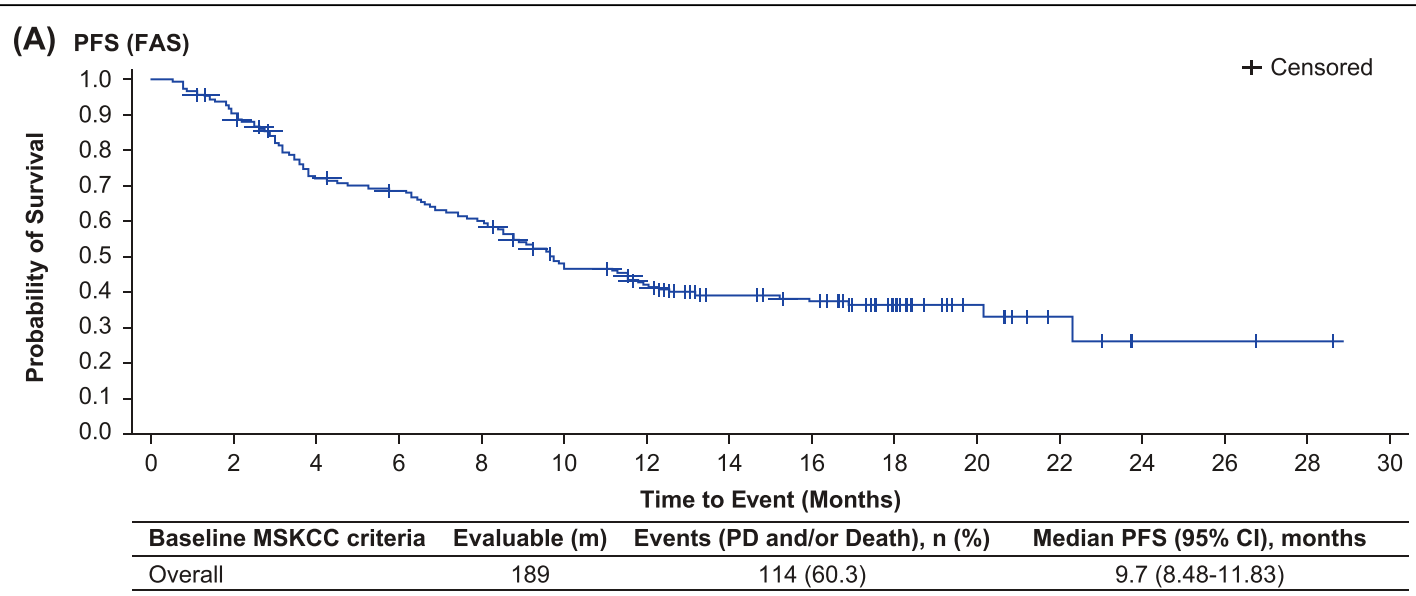

(B) PFS by MSKCC risk category (FAS)

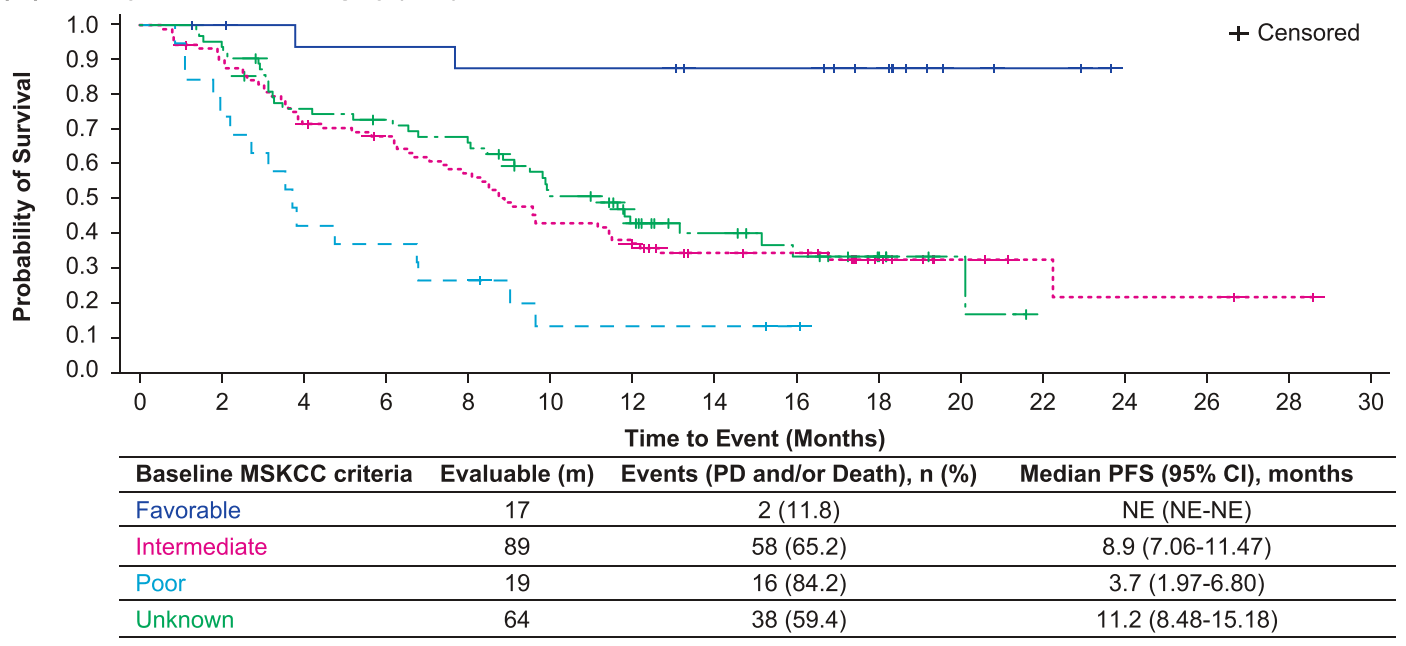

(C) PFS by IMDC risk category (FAS)

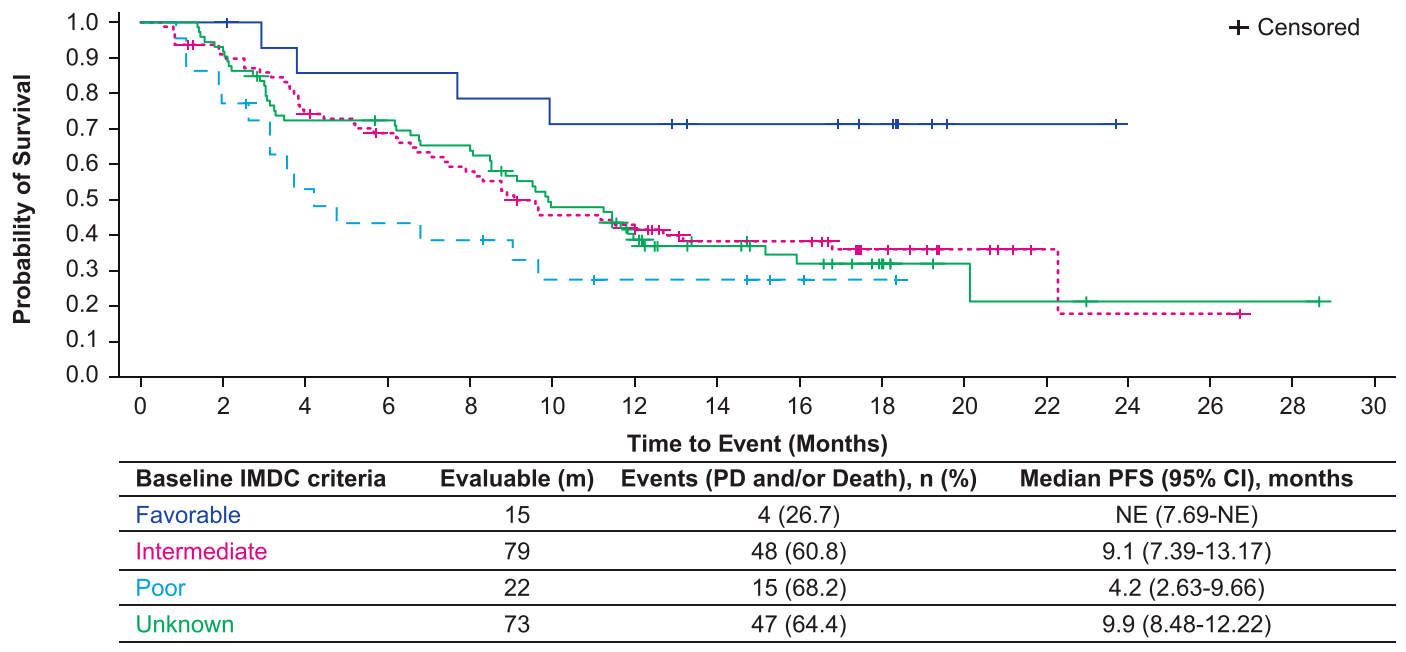

$\mathrm{Cl}=$ confidence interval; FAS = full analysis set; IMDC = International Metastatic Renal Cell Carcinoma Database Consortium; MSKCC = Memorial Sloan Kettering Cancer Center; $P D=$ progressive disease; PFS = progression-free survival

Fig. 1 Kaplan-Meier plot for PFS for (A) all patients, (B) MSKCC risk categories, and (C) IMDC risk categories (FAS) 